\title{
Obituary
}

\section{Frank J Ayd Jr, MD (1920-2008)}

Neuropsychopharmacology (2008) 33, 3255-3256; doi: 10.1038/npp.2008.180

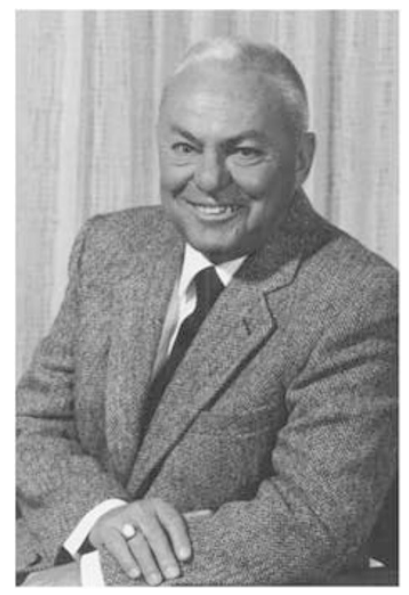

Frank Ayd was a person of faith and science who made singular contributions in both areas. When Frank was born, suicide was still a sin and in many countries a crime. The only medicines to treat mental illness were barbiturates, bromides, and paraldehyde. Despite Kraepelin's contributions to nosology and Freud's explorations of neurosis, diagnosis, and etiology remained primitive. For many, major depression was 'The Noonday Demon' and psychosis was attributed to flawed character development, faulty parenting, sin, or sexual indulgence.

Frank was the son of a pediatrician and helped in his father's office. He entered medical school at the start of World War II with thoughts on pediatrics or medicine. There was little to attract him to psychiatry beyond ECT, insulin coma, and asylum care. Fate intervened halfway through his pediatric residency when the US Navy drafted him to the psychiatric staff at Perry Point VA Hospital. His father's advice was, 'do what you can to keep them in good physical health, if nothing else.'

Frank began his practice of psychiatry at Baltimore in 1951 and 'something else' became possible when Smith Kline and French Laboratories approached him to evaluate potential CNS compounds coming out of the lab. Frank's inpatient base in Baltimore was at Franklin Square Hospital (where he was Chief of Psychiatry from 1955 to 1962) and later at Taylor Manor Hospital. In 1953, Frank became the first clinician in the United States authorized by the FDA to study chlorpromazine in patients. In 1955, he published the results initiating the modern era of psychopharmacology in this country.
From then on, two principles governed Frank's approach to the new discipline. He wanted to observe the effects for himself, both good and bad; and over the next 50 years, he studied every neuroleptic that appeared on the market with only two exceptions. Second, he was certain that for progress to occur, etiology must be linked to diagnosis and treatment. This required a close collaboration between clinicians and basic scientists. How Frank pursued this latter goal is the story of the CINP and the ACNP.

Frank was a devout Catholic; he and his wife Rita raised 12 children to whom he promised that the professional obligations would never preempt family ties. That resolve was tested early in 1957 when his daughter Theresa's first communion coincided with plans to attend a meeting of European psychopharmacologists in Milan. Frank resolved the dilemma in a characteristically creative manner. He accepted an invitation as a guest of Pope Pius XII, and his daughter made her first communion in Saint Peter's Basilica and Frank went on to Milan to help found the CINP. The following year, Frank attended the first CINP meeting held in Rome in September 1958. The Pope addressed the Congress after Frank vetted his remarks for scientific accuracy.

A few years later, Frank played a key role in breaking down the historic barriers between religion and psychiatry when the Pope invited him to live in Rome as a consultant to the Vatican leading up to Vatican II. Frank became the first American layman on the faculty of the Pontifical Gregorian University and broadcast regularly over Vatican Radio.

Two years later, Frank had helped found the CINP in Europe, and he became one of the six members of an organizing committee that planned and launched its American counterpart, the ACNP, in 1961. It was Frank's hope that every nation would eventually do likewise.

Frank Ayd was a short, stocky man with a signature crew cut who was bursting with energy, enthusiasm, and optimism. His literary output and scientific productivity were prodigious. He is credited with authorship of more than 400 scientific articles, and edited, authored, or contributed to more than 50 books. Several of his contributions are classics in the field of psychopharmacology, including his 1961 JAMA 'Survey of drug-induced extrapyramidal reactions,' the only article by a psychiatrist in JAMA's 100 citation classics.

Frank lectured in 47 foreign countries and taught in 170 medical schools around the globe. His desire to disseminate knowledge led him to edit and publish The International Drug Therapy Newsletter (now Psychopharmacology Review) and The Medical Moral Newsletter.

The scope of Frank's interests and influence can be gauged by the publications in just one productive year. In 1967, he authored 79 articles and essays equally distributed between medication side effects, therapeutic efficacy, and moral or ethical issues. Side effects included specific conditions (dyskinesia, eye pigmentation, and seizures) 
and generic issues (tranquilizer overuse in the elderly, polypharmacy, and drug withdrawal). Treatment efficacy included medication in every drug category and disorders in every major diagnosis as well as generic topics (plasma levels, safety and efficacy, and 'drug holidays'). Ethical and moral issues included abortion, contraception, sex education, sterilization, violence, drug abuse, and venereal disease.

Frank Ayd received numerous regional, national, and international awards acknowledging his scientific and literary accomplishments in the secular, spiritual, and scientific worlds. He was a Life Fellow of the APA and the ACNP, a member of the National Association of Science Writers and was listed in Leaders in American Science, American Men of Medicine and American Catholic Who's Who. He received four Honorary Doctorates in Law and an Honorary Doctorate of Science from American Universities.
He was the recipient of the Vincent Pallotti Award, the Open Mind Award in Psychiatry and the American Writers Association Award. Frank was twice honored by the ACNP for distinguished service in 1988 (Paul Hoch Award) and in 1993.

Frank continued to write, lecture, and edit until his death in March 2008. He is survived by his wife of 64 years, Rita, 11 children, 32 grandchildren, and 38 great grandchildren.

Frank Ayd was a unique role model and mentor to countless family members, patients, colleagues, medical students, residents, and those who shared his faith. He will be sorely missed and never replaced.

Barry Blackwell ${ }^{1}$

${ }^{1}$ Fox Point, 6855 Lake Drive, 53217, WI, USA 